\title{
Risk Assessment and Strengths Based Case Management in Elderly Care- Scope of Social Work Practice
}

\author{
Minimol $\mathrm{K}^{*}$
}

\section{Abstract}

Social workers have a significant role in ensuring the wellbeing of older people. Social work brings a range of specialized skills and methods of interventions in improving the quality of life of older adults. Conducting proper assessment is an important task of social workers while engaging in the provision of support services. In contrast to the ubiquitous deficit-based assessments, strengths-based assessments provide social work practitioners with methods to assess strengths and abilities and thereby develop strengths-based interventions. Though risk-assessment is necessary to prevent problems occurring, understanding clients' strengths is an integral resource in the helping process. Assessments giving equal importance to risks and strengths are inevitable in formulating and implementing specific activities to facilitate their independent living in the community. This paper highlights the significance of biopsychosocial assessment, risks/strengths assessment and strengths-based case management of older adults. This paper also presents an inventory of risks and strengths reported by older adults who attended case work and counselling sessions with the author during her

*Department of Social Work, Vimala College, Thrissur, Kerala, India; minikjose@gmail.com 
role as a social worker in a multidisciplinary community health care setting in Australia.

Keywords: Social Work, Case Management, Risk Assessment, Strengths based approach, Elderly, Risk management

The global demographic trend shows significant ageing of the population. The global share of older people (aged 60 years or over) increased from 9.2 percent in 1990 to 11.7 percent in 2013 and will continue to grow as a proportion of the world population, reaching 21.1 percent by 2050 (UN, 2013). Though older adults experience discrimination, marginalization, and prejudice, most of them are very active and also willing to contribute a great deal to the society.Old age is also a stage of life where people feel losing their independence, and also experience a loss of control over their lives causing physical and psychosocial problems. Physical changes, physiological decline, chronic health conditions, change in socioeconomic status, psychosocialconcerns, etc., call for a multidisciplinary approach to provide comprehensive services to the elderly. Health professionals such as medical doctor, nurses, physiotherapists, occupational therapists, podiatrists, dietitian and social workers are included in this multidisciplinary team. Each professional have unique contributions to the assessment and interventions and promoteinterprofessional collaboration for the better care of the elderly. Social workers, in their role as team members, exert significant influence in guiding team recommendations to improve the quality of life of the elderly. As the number of elderly persons with complex health needs is increasing, a comprehensive assessment is of paramount importance for initiating their care.

\section{Social Work Assessment}

Assessment refers to a process occurring between social work practitioner and client, in which information is gathered, analysed and synthesized to provide a concise picture of the client and his or her needs and strengths(Hepworth, Rooney, Gottfried,\&Larsen, 2010). This assessment is found to be a continuous process throughout the entire course of intervention or therapy as clients often disclose new information as problem-solvingprogress, and 
sometimes new perspectives emerge as the result of knowing the client better. Hence, it is critically important to understand that there is no distinct demarcation between assessment and intervention in social work practice.

Assessment of the elderly can be defined as: "a multidimensional, usually interdisciplinary, diagnostic process used to quantify an elderly individual's medical, psychosocial and functional capabilities and problems with the intention of arriving at a comprehensive plan for therapy and long-term followup"(Rubenstein, Campbell,\& Kane, 1987). Health assessment provides a structured way of identifying health issues and conditions that are potentially preventable or amenable to interventions to improve health and quality of life(The Department of Health, Australian Government, 2014). In addition to assessing a person's health status, a health assessment is used to identify a broad range of factors that influence a person's physical, psychological and social functioning.

\section{Bio-psycho-social perspective in assessment}

All humans are influenced by and exist within at least four major dimensions, biological, psychological, social, and spiritual. The biopsychosocial approach was developed at Rochester, New Yorkin 1977 by Dr.George Engel and Dr.John Romano. While traditional biomedical models of health care focus on pathophysiology and other biological approaches to disease, the biopsychosocial approach systematically considers biological, psychological, social, spiritual and cultural factors and their complex interactions in understanding health, illness, and health care delivery.The social worker will also need to consider the physical safety of clients' current living situation.Overall, there is strong evidence that a collaborative biopsychosocial model is superior to thetraditional biomedical model of patient care (Gatchel et al.,2007).

Biopsychosocial assessment includeseliciting information about the risks of the older adults- bothinternal and external. The assessment also incorporates older adults' perceived sources of life strengths and capabilities. Risk assessment is very crucialto prevent potential harm to the older people.Internal risk factors include medical 
co-morbidities, substance abuse, mental illness and suicide ideations, cognitive and sensory impairment, impairment in activities of daily living, malnutrition, etc. External risk factors include lack of social network, dependence on a caregiver, living alone, lack of community resources, inadequate housing, unsanitary living conditions, adverse life events and high-crime neighborhood and poverty. The assessment also focuses on 'red flags' such as repeated hospital admissions, self-neglect, unexplained weight loss, refusal to needed assistance, accidents, victimization, and exploitation. Older adults' self-perceptions and self-appraisals of their life strengths have an important influence on their health and well-being. Poor appraisals and negative perceptions of internal strengths leadto greater helplessness and loss of control and positive appraisals, and positive perceptions of internal strengths lead to higher motivation to preserve and maintain resilience in late life (Schlegel et al., 2011).

\section{Risk assessment and Risk management in older adults}

Risk management aims to minimise the likelihood of adverse events in the life of older adults. It provides the opportunity for targeted interventions to minimise the causal factors to achieve the best possible outcome and deliver safe, appropriate, effective care. The specific risks identified by the author during her role as social work professional in a community health care setting in Australia are given below. The risk management strategies, which are preventative, responsive and supportive measures to reduce the potential negative consequences of risksare also included in the table.

\begin{tabular}{|l|l|l|}
\hline Area & Risks & Risk management strategies \\
\hline Mental health & $\bullet$ Depression & $\bullet$ Periodical mental status \\
& • Suicide ideations & examination \\
& • Self-harm & - Provide information and \\
& $\bullet$ Self-neglect & contact details ofemergency \\
& & services such as suicide \\
& & prevention, ambulance, \\
& & hospitals, Counselling \\
& & services \\
\hline Physical health & $\bullet$ Repeated & - Ensure appropriate and \\
\hline
\end{tabular}




\begin{tabular}{|c|c|c|}
\hline & $\begin{array}{l}\text { hospitalization } \\
\text { - Non-attendance of } \\
\text { follow-up } \\
\text { appointments } \\
\text { - Non-compliance } \\
\text { with medication } \\
\end{array}$ & $\begin{array}{l}\text { timely medical help -liaise } \\
\text { with family/ support } \\
\text { services } \\
\text { - Ensure availability and } \\
\text { affordability of medication }\end{array}$ \\
\hline $\begin{array}{l}\text { Social } \\
\text { relationships }\end{array}$ & $\begin{array}{l}\text { - Loneliness } \\
\text { - Isolation } \\
\text { - Social exclusion }\end{array}$ & $\begin{array}{l}\text { - Follow up by health } \\
\text { professionals } \\
\text { - Linking with support } \\
\text { services in the community } \\
\text { especially neighbours and } \\
\text { immediate family members } \\
\text { - Arrange volunteers' visits }\end{array}$ \\
\hline Housing & $\begin{array}{l}\text { - Poor lighting } \\
\text { - Slippery floor } \\
\text { - Obstruction in the } \\
\text { walkways } \\
\text { - Unstable and } \\
\text { unsuitable furniture } \\
\text { and appliances } \\
\text { - Inappropriate } \\
\text { location of toilets } \\
\text { and lack of grab } \\
\text { rails } \\
\text { - Too long or steep } \\
\text { stairs and lack of } \\
\text { handrails } \\
\text { - Unsanitary living } \\
\text { conditions } \\
\text { - Lack of proper } \\
\text { blankets or } \\
\text { mosquito nets }\end{array}$ & $\begin{array}{l}\text { - Periodic house checks by } \\
\text { health professionals, } \\
\text { especially by social } \\
\text { workers, occupational } \\
\text { therapists or } \\
\text { physiotherapists } \\
\text { - Arrange financial assistance } \\
\text { by welfare organizations to } \\
\text { do modifications } \\
\text { - Provide safety awareness to } \\
\text { older persons and careers } \\
\text { - Awareness generation } \\
\text { programmes for public and } \\
\text { builders regarding barrier- } \\
\text { free and safe households } \\
\text { - Periodical assessment of } \\
\text { frailty and fall risks } \\
\text { - Cleaning by family } \\
\text { members/volunteers/welf } \\
\text { are organisations }\end{array}$ \\
\hline $\begin{array}{l}\text { Physical } \\
\text { surroundings }\end{array}$ & $\begin{array}{l}\text { - Uneven walkways } \\
\text { outside house } \\
\text { - Antisocial activities } \\
\text { in neighbourhood }\end{array}$ & $\begin{array}{l}\text { - Periodic checks by health } \\
\text { professionals or welfare } \\
\text { organizations } \\
\text { - Inform and request } \\
\text { protection from police }\end{array}$ \\
\hline $\begin{array}{l}\text { Abuse } \\
\text { violence }\end{array}$ & $\begin{array}{l}\text { - Abuse by carers, } \\
\text { family members, } \\
\text { helpers } \\
\text { - Physical, emotional }\end{array}$ & $\begin{array}{l}\text { - Provide information } \\
\text { regarding abuse and how } \\
\text { to seek help. } \\
\text { - Provide legal awareness }\end{array}$ \\
\hline
\end{tabular}




\begin{tabular}{|l|l|l|}
\hline & and financial abuse & - Break 'culture of silence.' \\
\hline Transportation & $\begin{array}{l}\text { - Lack of transport } \\
\text { facility } \\
\text { - No one to } \\
\text { accompany }\end{array}$ & $\begin{array}{l}\text { - Ensure safe transport } \\
\text { - Arrange transport with the } \\
\text { help of family members/ } \\
\text { welfare organizations }\end{array}$ \\
\hline $\begin{array}{l}\text { Food and } \\
\text { Nutrition }\end{array}$ & $\begin{array}{l}\text { - Unexplained } \\
\text { weight loss and } \\
\text { malnutrition } \\
\text { - Lack of food }\end{array}$ & $\begin{array}{l}\text { - Ensure proper eating } \\
\text { - Liaise with career/ family } \\
\text { members }\end{array}$ \\
\hline $\begin{array}{l}\text { Cognitive } \\
\text { capacity }\end{array}$ & $\begin{array}{l}\text { - Impairment } \\
\text { - Memory loss, } \\
\text { confusion }\end{array}$ & $\begin{array}{l}\text { - Periodic assessment and } \\
\text { support services }\end{array}$ \\
\hline
\end{tabular}

\section{Strengths Assessment and strengths based Case Management}

There is a significant difference in the medical model of case management and strengths-based case management. In the medical model, the emphasis is to ameliorate the diagnosed problem of the client, where the emphasis is on the helping professional's expertise and power (Freidson,1988). Instead, in the strengths-based case management, the professional's help is to get the most out of what the client can do. This approach helps the client to compensate for what they cannot do with their residual capabilities and enhance the client's capacity to carry out their routine with increased wellbeing. For older adults with chronic health conditions, though they are getting adequate services to meet their medical needs, other matters such as financial problems, transportation issues, inadequate or unsuitable housing, social isolation, grief and loss issues, etc. cause significant discomfort in them resulting in the decline of quality of life. Strengths-based assessments of older people facilitate strengths-based case management that gives importance to the individual and his or her environment. The main focus of this model is to develop the client's internal and external resources with their full participation in the decision-making process.

Seligman (1998) stated, "psychology is not just the study of weakness and damage: it is also the study of strength and virtue. 
Treatment is not just fixing what is broken; it is nurturing what is best within ourselves". Strength-based, positive interventions are consistent with and derived from models and principles of strength-based, positive psychology. Strengths-oriented practice implies that social workers should assess all clients in light of their capacities, talents, competencies, possibilities, visions, values and hopes (Saleeby,2002). These interventions serve to assist participants to live more productive, empowered, and satisfying lives (Orsulic-Jeras, Shapiro, \&Britton, 2003). "Strength-based positive interventions involve (a) identifying strengths, rather than pathology; (b) using a biopsychosocial model, rather than a strictly biomedical model; (c) focusing on strengths, rather than on illness; (d) supporting coping, change, and growth, rather than suppressing negative factors; (e) emphasizing possibilities, options, and success, rather than past emotional problems; (f) involving active participation, rather than passive reception; (g) focusing on uniqueness, rather than on reductionist categories or labels; and (h) focusing on what is right and how, rather than on what is wrong or why" (Orsulic-Jeras, Shapiro, \& Britton,2003). Saleebey (1992c) suggests that individuals and groups "have vast, often untapped and frequently unappreciated reservoirs of physical, emotional, cognitive, interpersonal, social, and spiritual energies, resources and competencies" (p. 6). By reinforcing the strengths, the older adults find more meaning and purpose in their lives which will lead to graceful ageing. Strength-based positive interventions have the potential to increase resilience, well-being, and life satisfaction while decreasing distress and pain. Jansen, B, Regenmortel, T., Abma,T. (2011) found that although older people often experience stressful life events, they possess and mobilize different sources of strength that help them to adapt constructively to developmental stressors.

The following table gives a list of strengths reported by the clients and identified by the author during her direct social work practice with older adults in a community health care setting in Australia. The table also provides strategies to build on those strengths. 


\begin{tabular}{|c|c|c|}
\hline $\begin{array}{c}\text { Life } \\
\text { domain }\end{array}$ & Strengths & $\begin{array}{c}\text { Strategies to enhance and } \\
\text { utilize the strengths }\end{array}$ \\
\hline Personal & $\begin{array}{l}\text { - Resilience- Positive } \\
\text { adaptation in the context } \\
\text { of adversities } \\
\text { - Positive feelings about self } \\
\text { - Satisfaction/ contentment } \\
\text { about own life }\end{array}$ & $\begin{array}{l}\text { - Create opportunities to } \\
\text { share older adults' } \\
\text { experience with peers or } \\
\text { young adults } \\
\text { - Acknowledge and } \\
\text { appreciate their successes } \\
\text { and positive coping } \\
\text { abilities }\end{array}$ \\
\hline Family & $\begin{array}{l}\text { - Maintaining relationships } \\
\text { with family members } \\
\text { - Extending support to } \\
\text { children } \\
\text { - Looking after } \\
\text { grandchildren }\end{array}$ & $\begin{array}{l}\text { - Acknowledge and } \\
\text { appreciate their } \\
\text { contributions and support } \\
\text { by their family and society } \\
\text { - Encourage grandchildren } \\
\text { to express their gratitude }\end{array}$ \\
\hline Social & $\begin{array}{l}\text { - Participation in social } \\
\text { activities } \\
\text { - Volunteering in welfare } \\
\text { programmes } \\
\text { - Maintaining relationship } \\
\text { with neighbours and } \\
\text { friends } \\
\text { - More empathetic and } \\
\text { supportive to others }\end{array}$ & $\begin{array}{l}\text { - Encourage older adults to } \\
\text { participate. } \\
\text { - Formulate specific } \\
\text { programmes to ensure } \\
\text { their participation and } \\
\text { utilize their practical } \\
\text { wisdom } \\
\text { - Arrange formal interaction } \\
\text { with young people and } \\
\text { children }\end{array}$ \\
\hline Health & $\begin{array}{l}\text { - Acceptance of one's } \\
\text { vulnerability, fragility } \\
\text { (non-resistance in using } \\
\text { aids such as walking stick, } \\
\text { walker,etc.) } \\
\text { - Willingness to seek help } \\
\text { - Openly share one's } \\
\text { problem } \\
\text { - Role of a survivor than a } \\
\text { victim }\end{array}$ & $\begin{array}{l}\text { - More opportunities for } \\
\text { physical activities } \\
\text { - Incentives and } \\
\text { encouragement to people } \\
\text { who maintain their positive } \\
\text { health status }\end{array}$ \\
\hline Housing & $\begin{array}{l}\text { - Adjustment to new } \\
\text { location } \\
\text { - Capacity to live alone }\end{array}$ & $\begin{array}{l}\text { - Provide/arrange facilities } \\
\text { to enhance independent } \\
\text { living }\end{array}$ \\
\hline Finance & $\begin{array}{l}\text { - Financial independence, } \\
\text { Regular income } \\
\text { - No extravagance }\end{array}$ & $\begin{array}{l}\text { - Involve older adults in } \\
\text { welfare programmes }\end{array}$ \\
\hline
\end{tabular}


Another tool that could be used to assess the strengths is the ROPES Model (Gray-beal, in development,). This acronym stands for Resources, Opportunities, Possibilities, Exceptions, and Solutions. This framework is used to guide both the general perspective and the specific questions of the practitioner.

The strengths-based approach creates feelings of usefulness to others among older adults. This will make them more socially engaged and productive through connecting themselves with activities that are meaningful to them. The approach focuses on what an individual can do, and what they want to be able to do; rather than focus on what they are not able to do. It encourages and enables people in making healthy life choices.

\section{Strengths-based case management for older adults}

Case Management is integral to contemporary social work practice with all client groups. Case management is a process to plan, seek, advocate for, and monitor services from different social services or health care organizations and staff on behalf of a client (National Association of Social Workers (NASW) Practice Standards, 2013). The Case Management Society of Australia (2016) defines case management as "a collaborative process of assessment, planning, facilitation and advocacy for options and services to meet an individual's holistic needs through communication and available resources to promote quality cost-effective outcomes".

In the current social work practice in the health care settings, social workers spend more than half their time on case management tasks. The strengths-based approach in social work practice focuses on improving the service delivery, support systems, resources and opportunities for older adults. Case management expands the range of needed services offered, and usually, this is provided by community agencies. The ultimate aim of social work case management is to optimize client wellbeing by delivering quality personalized services at the appropriate time. The important principles in this process are client's right to self-determination and empowerment which certainly make clients as active recipients of services. The clients actively participate in the decisionmakingprocess for choosing suitable services from the options 
offered by social workers and community agencies. The case management also aims at improving the social and emotional wellbeing of the client and attainment of personal goals. Despite many losses in the life of adults, case management promotes a sense of hope and graceful aging.

As stated above comprehensive needs assessment and risk assessment are important components of case management process. Care planning, service delivery, monitoring, and reassessment are other key components. Care planning is the process of developing an agreement between the client and social worker/case manager regarding risks identified, priorities made, outcomes to be achieved and services to be pursued for the goal achievement. With the participation of the client and significant others involved in the care of the client, a service package will be developed for each client. The social worker who works in such settings is expected to be well-familiar with the available resources and service alternatives in the community.

The following table gives an example of how a care plan can be madeto address a concern of inability to manage household tasks by an aged client.

\begin{tabular}{|c|c|c|c|}
\hline Concern & $\begin{array}{c}\text { Desired } \\
\text { outcome }\end{array}$ & $\begin{array}{c}\text { Assistance } \\
\text { required }\end{array}$ & Service Provider \\
\hline $\begin{array}{l}\text { Client } \\
\text { unable to } \\
\text { manage } \\
\text { household } \\
\text { tasks }\end{array}$ & $\begin{array}{l}\text { Client has a } \\
\text { clean and } \\
\text { hygienic } \\
\text { environment } \\
\text { Client's } \\
\text { improved } \\
\text { quality of life }\end{array}$ & $\begin{array}{l}\text { Referral to } \\
\text { community } \\
\text { agencies for } \\
\text { cleaning } \\
\text { service, } \\
\text { housekeeping, } \\
\text { shopping, meal } \\
\text { preparation }\end{array}$ & $\begin{array}{l}\text { Volunteer or paid } \\
\text { support workers from } \\
\text { community agencies } \\
\text { OR } \\
\text { Mobilizing informal } \\
\text { support from family } \\
\text { members/relatives if } \\
\text { available }\end{array}$ \\
\hline
\end{tabular}

To formulate a proper care plan, the social worker should be skilled in initiating and facilitating dialogue with the clients regarding where they are at present, where they want to go, when and how and their confidence level to undertake the activity to achieve expected outcomes. This structured care planning helps older adults to believe that independent living in the community is possible with adequate support. This promotes client independence 
and healthy interdependence with informal and formal support systems. The strengths-based case management will only be successful if there is continuous monitoring of the implementation of the care plan. An ongoing contact with the client by the case manager is important to make the interventions more sustained, individualized and effective. This will prevent unnecessary hospital admissions and institutionalization of elderly.

The strengths-based case management model also ensures an emergency crisis plan for older adults. Suppose the client has repeated falls in the past and if there is the likelihood of further falls due to frailty, an alert system or telecare is to be developed. In many developed countries there is personal alarm system introduced by organisations such as Red Cross. Here, the elderly person wears an alarm system in the form of a pendant. In the case of emergency, e.g.,Afall, the person can press the button on the pendant, and this will help the professionals or volunteers in the alarm service to talk to the client via loud speaker and assess the situation to provide immediate assistance.

\section{Conclusion}

It is important to understand that the strengths-based approach is not about ignoring the problems and challenges experienced by people. Rather it is a collaborative approach to identifying resources, strengths, and possibilities and encourage people to build on those positive attributes and capabilities. One of the advantages of the strengths-based model is that it celebrates the differences in people, framing diversity as a strength. Furthermore, social workers are uniquely positioned to consider the risks in the lives of older adults to create a safe and supportive living environment. The risk management strategies and strengths-based interventions increase a positive sense of self-worth, competence, hope and optimism. It enhances older people's autonomy, reducesmorbidity and mortality and improves their quality of life. 


\section{References:}

Case Management Society of Australia (CMSA) (2006): Case Management and Community Care: A Discussion Paper, Case Management Society of Australia, Sydney.

Engel, G. L. (1977). The need for a new medical model: A challenge for biomedicine. Science, 196(4286), 129-136. doi: http://dx.doi.org/10.1126/ science.847460.

Gaitz,C. (1987) Multidisciplinary team Care of the elderly, the role of psychiatrist 34(2):p 131

Gatchel, R. J., Peng, Y. B., Peters, M. L., Fuchs, P. N., \& Turk, D. C.(2007). The biopsychosocial approach to chronic pain: Scientific advances and future directions.Psychological Bulletin, 133.581-624

Graybeal, C. (in development). The ROPES Tool for Assessment of Strengths

Hepworth, D.H., Rooney H.R., Glenda D, Strom-Gottfried, Kim(2010).Theory and Skills in Social Work. India Edition

Janssen,M.B.,Regenmortel V, Abma, A.T. (2011). Identifying sources of strength: resilience from the perspective of older people receiving community long-term care, European Journal of Ageing. Sep 2011; 8(3); pp.145-156

NASW Standards of Social Work Case Management.Retrieved from https://www.socialworkers.org/practice/naswstandards/case managementstandards2013.pdf

Orsulic-Jeras, S., Shephard, J. B., \& Britton, P. J. (2003).Counseling older adults with HIV/AIDS: A strength-based model of treatment. Journal of Mental Health Counseling, 25 (3), 233 - 244. Retrieved

from:http:// feltoninstitute.org/articles/StrengthBasedmodelof treatmentarticle

Rubenstein, L. Z., Campbell,L.J., \&Kane, R.L (Guest Editors)(1987).

Geriatric assessment. Clinics in Geriatric Medicine; 3:1 
Saleebey, D. (1992c) 'Introduction: Power in the People', in The strengths perspective in social work practice, (ed.) New York: Longman.

Saleeby,D.(2002). The Strengths Perspective in Social Work Practice (3rded.) Boston, Pearson/Allyn \& Bacon

Sandi, C (2011) Risk assessment and intervention for vulnerable older adults, Issue: BCMJ, 53(8).pp421-425

Schlegel, J. A. Hicks, L. A. King, and J. Arndt.(2011). "Feeling like you know who you are: perceived true self-knowledge and meaning in life," Personality and Social Psychology Bulletin, vol. 37 , no. 6 , pp. $745-756$

Seligman, M.E.P. (1998). Learned Optimism.Second edition. New York: Pocket Books (Simon and Schuster)

The Department of Health, Australian Government, 2014 Retrieved from

http://www.health.gov.au/internet/main/publishing.nsf/Co ntent/mbsprimarycare_mbsitem_75andolder

UN Report, World Population Ageing (2013) retrieved from http://www.un.org/en/development/desa/population/publi cations/pdf/ageing/WorldPopulationAgeing2013.pdf on 1/ $11 / 2014$ 